Human Resource Management Journal, Volume 21, Number 3, 2011, Pages 335-354

Desired goals and actual outcomes of e-HRM

Emma Parry and Shaun Tyson

Cranfield School of Management

Dr Emma Parry

Cranfield School of Management

Beds MK43 0AL

01234754808

emma.parry@cranfield.ac.uk 


\title{
Desired goals and actual outcomes of e-HRM
}

\begin{abstract}
Much discussion exists in the academic literature about the potential goals of e-HRM, but few scholars have looked at whether these goals are actually realised and what factors have an impact on this. This study examined the goals stated by organisations for the introduction of e-HRM, whether these goals were actually achieved, and the factors affecting this through ten case studies with a range of UK organisations. The results demonstrated that e-HRM is introduced in order to improve efficiency, service delivery, standardization and organisational image, to empower managers and transform HR into a more strategic function. Efficiency, service delivery and standardisation goals were commonly realised. Some evidence of a transformational impact of e-HRM was found, as HR staff had more time and information to support the organisation in achieving its business strategy. However, no evidence was found of an actual increased involvement of HR in business decision making.
\end{abstract}

The authors thank Doone Selbie and Ray Leighton for helping to conduct this research, the Chartered Institute for Personnel Development (CIPD) for funding the research and the staff in each case study organisation for giving their time. 


\section{Introduction}

The use of e-HRM has increased greatly over recent years with most large organisations now using technology to some extent in their management of human resources (CIPD, 2005). E-HRM may improve efficiency and facilitate a shift in HR role to a more strategic level. The growing literature on this topic has discussed a range of broad goals for e-HRM introduction (Ruel, Bondarouk and Looise, 2004; Marler, 2009), including cost and efficiency savings, strategic aims and improvements in client services. However, few scholars have examined empirically whether organisations are achieving their goals through the introduction of e-HRM (Strohemeier, 2007). The goals of efficiency, improved service delivery and a strategic HR function are clearly beneficial for organisations introducing eHRM. In order that organisations realise the benefits of new technology, rather than wasting their resources on introducing e-HRM in a way that will not enable them to achieve their goals, it is important to establish whether the commonly espoused goals of e-HRM introduction are actually achieved and to examine the factors that might affect this. In this study, we address this need through an investigation of e-HRM in ten case study organisations. We ask three research questions: firstly, what are the stated goals for organisations introducing e-HRM? Secondly, what are the actual outcomes experienced by organisations as a result of the introduction of e-HRM? Finally, what factors affect the realisation of stated goals for e-HRM?.

\section{Defining e-HRM}

We define e-HRM as "a way of implementing HR strategies, policies and practices in organisations through a conscious and directed support of and/or with the full use of webtechnology-based channels" (Ruel et al.'s; 2004; p.365). E-HRM has a wide range of uses and may support particular HR activities - for example recruitment and selection, performance management, compensation and benefits, training and development, health and safety, employee relations, retention and policies on work-life balance (Enshur, Nielson 
and Grant-Vallone, 2002) and may be used to manage employee information across the entire employment cycle.

Thite and Kavanagh (2009) divided HRM activities into: transactional activities, that involve day-to-day transactions and record keeping; traditional HRM activities, such as recruitment, selection, planning, training, compensation and performance management; and transformational activities, that add value to the organisation, such as organisational development, talent management and learning. Over recent years, we have seen a shift in the delivery of transactional HRM from an approach which is "labour intensive" to one which is "technology-intensive" (Florkowski and Olivas-Lujan, 2006) whereby a large proportion of transactional activities are now delivered using software rather than by HR administrators. Indeed, the use of e-HRM has rapidly increased over recent years, with 77 per cent of UK organisations using some form of e-HRM in 2005 (CIPD, 2005). This increase has gone hand in hand with other changes in HR delivery such as the increased use of outsourcing and shared-service centres, with which e-HRM operates interdependently (Martin, Reddington and Alexander, 2008). While we acknowledge these other changes in HR service delivery, the main focus of our paper will be on the use of e-HRM, as defined above.

\section{The goals of e-HRM}

E-HRM's purpose is to support the achievement of HRM goals more generally. HR goals have traditionally been broken down into three types: being cost effective; improving services for internal customers; and addressing the strategic objectives of the business (Martin et al., 2008; Lepak and Snell, 1998). Ruel, Bondarouk and Looise (2004) added a fourth goal for e-HRM; to improve the global orientation of HRM. Martin et al. (2008) suggested that the drivers of e-HRM are to assist in the achievement of the HR function's transactional or transformational goals. Transactional goals focus on reducing cost or improving the productivity and service delivery of the HR function, while transformational goals focus on freeing up time for HR professionals to address more strategic issues and 
can be seen as sub-goals of the overall goal of the HR function to meet the strategic needs of the business (Ulrich, 1997; Paauwe, 2004).

Lepak and Snell (1998) posited that IT might have operational, relational and transformational effects on HR. Empirical evidence for the achievement of these goals is rare, although some authors have examined the outcomes of e-HRM, regardless of the goals for its introduction. Strohmeier (2007) suggested that the question of whether e-HRM is "able to transform HR into an appreciated business partner that provides value to the organisation is only parenthetically addressed" (p.28) and concluded that there is a need for further research into the impact of e-HRM in all three of Lepak and Snell's areas. Bondarouk and Ruel (2009) stated "organisations are definitely silent about whether their HR departments become more strategic with e-HRM" (p.508). We will use Lepak and Snell's (1998) framework as a basis for our discussion of the goals for e-HRM use. Despite being over ten years old, Lepak and Snell's (1998) three goals still provide a useful summary of the literature in this area. We will build on this framework using more recent work on e-HRM, and examine whether each goal is actually realised as an outcome of e-HRM use.

\section{Operational goals}

The idea of e-HRM improving efficiency or reducing costs has been supported by a number of authors (Ruel, Bondarouk and Looise, 2004; Marler, 2009). Operational benefits have also been suggested as an actual outcome of e-HRM. Hendrickson (2003) proposed there would be increased efficiency through "allowing more transactions to occur with fewer fixed responses" (p.383) in processes such as payroll. This is similar to Martin et al.'s "transactional" outcomes of e-HRM. Empirical research has supported the existence of efficiency gains through e-HRM, by reducing HR staff, increasing the speed of processes, reducing costs and releasing staff from administrative work (Strohmeier, 2007; Ruta, 2005; Ruel, et al. 2004). Indeed, Ruel et al. (2004) found that the most common outcomes of e- 
HRM were a reduction of costs and of the administrative burden on HR practitioners, although these outcomes were not generally measured.

\section{Relational goals}

Relational impacts of e-HRM might, for instance, provide employees and managers with remote access to HR information and increase their ability to connect with other parts of the company and outside organisations, so that they can perform HR activities themselves. This idea is linked with Ruel et al.'s (2004) suggestion that e-HRM can be used to improve HRM services including supporting managers and employees. While both Lepak and Snell's relational goal and the goal of improving service delivery espoused by Ruel et al. might improve the effectiveness of the HR function, these goals are slightly different: having direct effects in achieving general improvements in service delivery; and indirect effects in order to improve the effectiveness of the HR function by empowering managers to perform HR tasks themselves. We will therefore treat these as two separate goals.

Evidence for improvements to HR service delivery through increased accuracy of data entry or by simplifying processes has been provided by Gardner, Lepak and Bartol (2003) and also by Bondarouk, Ruel and van der Heijden (2009), who found that e-HRM use was positively related to perceptions of general HRM effectiveness in line managers and employees. Similarly, Payne et al. (2009) found that reactions to an online performance management system were more positive than those to a paper-based version of the same system.

\section{Transformational goals}

The transformational role allows people to communicate across geographic boundaries and share information, thereby playing an important role in supporting virtual teams and network organisations. Ruel et al. (2004) suggested that e-HRM has the capacity to transform the HR function by improving the strategic orientation of HRM. A strategic HR function is one in which HRM is "linked to the strategic management process of the business" (Wright and 
McMahan, 1992), meaning that HRM uses an integrated set of policies and practices developed to execute the company's implicit or explicit business strategy through managing the firm's human capital (Martin-Alcazar, Romero-Fernandez and Sanchez-Gardev, 2005).

There is some debate in the academic literature about whether a transformational impact of e-HRM can be achieved. Some researchers have indicated that e-HRM may assist the HR function in becoming a business partner (Ruta, 2005; Ruel et al., 2004) while others have suggested that e-HRM has not realised its potential to facilitate a more strategic role for the HR function (Tansley, Newell and Williams, 2001). Case study research from Ruel et al. (2004) and Olivas-Lujan, Ramirez and Zapata-Cantu (2007) provided evidence that e-HRM helped the strategic integration of e-HRM with the company strategy. Parry (forthcoming) also found a relationship between use of e-HRM and a more strategic HR function. However, Burbach and Dundon (2005) found that e-HRM was generally used for administrative rather than strategic decision making purposes; although they found that some firms with e-HRM had better HRM information compared to non e-HRM using companies. Gardner, et al. (2005) suggested that, rather than freeing up the time of HR practitioners, the introduction of e-HRM simply led to the replacement of administrative activities with technology related activities. It is therefore unclear whether e-HRM actually does result in a transformational impact on the HR function.

One of the weaknesses in the above literature is the tendency not to see improvements to the HR process (discussed here as improvements in efficiency or service delivery) as having a strategic value. Strategy is frequently "emergent" (Mintzberg and Waters, 1985) and follows stages of logical incrementalism, a situation where the speed of management processes is important for rapid response to new realities (Quinn, 2003). In this interpretation of strategy, the efficiency and effectiveness of management processes are as important as any other strategic objective. There is also some evidence that multiple processes of strategy creation help organisations to perform well (Hart and Banbury, 1994).

Ruel et al.'s (2004) empirical study suggested a fourth goal of e-HRM: to improve the global orientation of the firm through the standardisation of HR processes. By "global 
orientation", Ruel et al. (2004) referred to standardisation across units or departments rather than necessarily across geographical boundaries. We will therefore add a fourth goal to our examination, that of standardisation. The use of standardised processes allows an organisation to ensure that it is compliant with particular HR requirements, and improves the process of management therefore making a strategic contribution, since it enables faster and more accurate decision-making.

\section{Achievement of e-HRM goals}

We have listed five possible goals for e-HRM - efficiency, service delivery, strategic orientation, manager empowerment and standardisation. Scholars have agreed that e-HRM leads to considerable changes (Gueutal and Stone, 2005; Strohmeier and Kabst, 2009) but have rarely examined the outcomes of e-HRM compared to the initial goals for e-HRM introduction. We might presume that e-HRM systems, developed for efficiency gains, for improvements in service delivery or for a more strategic orientation for $\mathrm{HR}$, would achieve outcomes related to efficiency, service delivery and a strategic orientation respectively. However, there may be occasions when goals are not realised, so intended outcomes are not achieved, or when unintended outcomes are experienced. The idea that e-HRM systems introduced to achieve a particular goal will automatically lead to that outcome may be simplistic and unrealistic, as might be the idea that e-HRM will always lead to the same outcomes for the HR function.

Some authors have suggested that the impact of e-HRM depends on the nature of the HR function. Voermans and van Veldhoven (2007) found that those HR functions with a preferred role of strategic partner or change agent were more likely to be positive towards eHRM. Similarly, Marler (2009) argued that HR departments with an administrative orientation were more likely to have efficiency (transactional) goals for e-HRM, whereas those that already function as a strategic partner to senior management were more likely to have strategic goals. Despite these suggestions, the situations under which e-HRM may satisfy efficiency, effectiveness or strategic objectives have not generally been investigated. 
One exception to this is the single case study by Ruel, Bondarouk and Van der Velde (2007) showing that support from colleagues and managers and the level of information provided on the e-HRM application positively affected the perception of e-HRM. Our article will provide an initial exploratory investigation of the factors that might affect whether goals of e-HRM use are translated into outcomes.

Following the framework of the five goals identified above, we provide a structured examination of organisational goals for using e-HRM, the outcomes that are actually realised as a result of e-HRM use and the factors that affect this. Our research questions are:

1. What are the goals stated by organisations when introducing e-HRM?

2. What are the actual outcomes experienced by organisations as a result of the introduction of e-HRM?

3. What factors affect the realisation of stated goals for e-HRM?

\section{Methodology}

As HRM is a highly organisational specific activity (Jackson and Schuler, 1995; Tyson, 1995), we have adopted a qualitative case study methodology in ten organisations. While it was not possible to be fully representative of the population of organisations through ten case studies, we have selected a range of organisations so that e-HRM could be examined in a number of different contexts. Whilst qualitative information of this kind cannot be said to be generalisable to other contexts, it does allow us to provide a detailed initial exploration of the relevant issues.

Organisations were selected who had introduced e-HRM over a year before (so that the system was embedded within the organisation) from a range of industry sectors, at different stages in e-HRM implementation and with different e-HRM systems and experiences. The final sample was dependent on the agreement of each organisation to take part, so to this extent a convenience sample was used. It was felt that ten case studies was a sufficient number of organisations in which to explore a range of goals and outcomes 
of e-HRM in a qualitative study. The case studies consisted of visits, between June 2006 and January 2007, where interviews with senior HR practitioners (including those responsible for the introduction of e-HRM) and HR users of e-HRM, as well as managers and employees where they were direct users of the system were held, and related documentation gathered as appropriate to the case. Ruel et al. (2004) proposed that conversational interviews such as those used in our study are appropriate for case studies of e-HRM use. The number of interviewees for each case study was dictated by the advice of the HR Manager, the organisational structure, end users of e-HRM and availability of interviewees. In BSkyB and Norwich Union, focus groups with employees were conducted to enable us to talk to more employees. In total, 70 interviews and five focus groups were undertaken, as shown in table 1.

(INSERT TABLE 1 ABOUT HERE)

An interview protocol was developed based upon the e-HRM literature and discussions within the research team. For HR managers, this contained a series of questions about the reasons for the introduction of e-HRM, its implementation and the impact that it had had within the organisation. For managers and employees, the interviews focused on their use of the system and the impact that e-HRM has had on them and on their perceptions of the HR function. In addition, a number of questions about the organisation and HR structure were asked. These protocols were first circulated to three HR practitioners and changes were made based upon their feedback.

Interviews were not recorded, due to concerns among interviewees about confidentiality. Detailed notes were taken and checked with interviewees for accuracy. Interview data were analysed using NVivo to identify themes. This analysis was conducted in two stages. Firstly, the analysis followed a deductive or top down process. Information that provided evidence for the existence of a goal or outcome relating to the five themes identified from the literature was categorised firstly as a goal or outcome and then into one of the themes. At the same time, information that did not fit into one of these five categories was coded all together into a single separate category. This information was then re-coded 
inductively by identifying themes that emerged from the data. This allowed us to identify additional goals or outcomes emerging from the case studies and also to identify factors that might affect the realisation of goals.

\section{Results}

The ten case study organisations and their use of e-HRM are summarised in table 2 in order to explain the context under which each organisation was operating.

\section{(INSERT TABLE 2 ABOUT HERE)}

The themes identified from the data are discussed below in relation to the broad goals for e-HRM use and whether these were realised through actual outcomes. For ease of analysis, the goals espoused by each organisation and the actual outcomes in relation to these goals are first presented in table 3.

\section{Goals for the introduction of e-HRM and the realisation of these goals (INSERT TABLE 3 ABOUT HERE)}

The case studies provided some evidence for all five of the goals suggested in our framework. These are presented in the order of significance (i.e.by number of case studies that mentioned them).

\section{Operational and Efficiency}

Efficiency or operational effectiveness was the most commonly mentioned goal for introducing e-HRM, appearing in all ten case study organisations. The nature of planned efficiencies varied between organisations. Organisations introduced e-HRM to reduce headcount within the HR function, to improve cost effectiveness, remove the use of paper in HR processes or to improve the speed of processes. An interviewee at Cancer Research UK explained that: 
Previously shortlisting [of candidates] was often delayed due to the unreliability of surface mail. In addition, the need to input data slowed the process down and created a huge task for the Resourcing Team ......this can be managed more efficiently using an online system.

Nine organisations had realised efficiency savings as a result of introducing e-HRM. Some organisations had reduced their HR headcount as a result of using e-HRM, but (where figures were available) these reductions were relatively small. Organisations had also experienced direct cost reductions and claimed to have achieved faster HR processes, although many had not measured these changes. In most organisations, the automation of processes and the direct entry of information by managers removed the need for duplicate keying of data by the HR administration team, meaning that the amount of time needed for transactions was reduced considerably. This was true of the use of e-HRM for appraisals and compensation planning within IBM and for salary reviews, bonus ratings and absence recording within $\mathrm{BOC}$ and Nortel. However, BSkyB found that the volume of calls to its $\mathrm{HR}$ call centre increased after the introduction of e-HRM, although this was expected to drop as people became more familiar with the system.

\section{Service Delivery}

Eight organisations had goals for improving service delivery. An interviewee from BSKyB explained that they wanted to:

Improve customer satisfaction for different segments of customers so that line managers can do things quicker and more easily and also to respond to the needs of the business by enabling sickness absence to be managed more easily.

Similarly, the CPS wanted to improve and rapidly update specialist knowledge of prosecution among lawyers. Cancer Research UK wanted to improve HR credibility:

Previously there were no reports to drive decision-making so management decisions were not based on reliable and accurate information. HR was seen as responsible 
for producing this information but didn't have the tools to provide it. The information needs to be accessible and self-service means that it is.

Seven organisations provided evidence that service delivery goals were being realised. Improved accuracy of the information contained in HR systems was achieved by removing duplicate keying of data, users had more easy access to information or training materials and there was improved accuracy and availability of data for use in management decision making.

The introduction of e-HRM had significantly reduced the transactional work of the HR administration teams in Cancer Research UK, allowing the HR function time to work on more complex or value added tasks, and to spend more time advising managers. The resourcing team was more customer-focused and proactive in recruitment, recruitment administrators' had been re-named 'recruitment advisors' to reflect this and the processes were more transparent. A manager from BSkyB described how:

Previously we would submit paper forms that would be passed from person to person. These would get lost and then we would get accused of never submitting the form in the first place. The new system means that we can find where an action is in the process at any one time.

Interviewees in BOC and IBM suggested that e-HRM may actually have an unintended negative effect on service delivery by depersonalising HR provision.

\section{Manager empowerment}

Six organisations had goals for manager empowerment through the development of management capability to conduct HR activities, such as recruitment, performance management and updating information. However, only three organisations provided evidence that this empowerment was being realised. In BSkyB and Nortel managers had been given increased HR responsibility and the online support to conduct HR activities and 
had become more effective at doing so. In IBM, the provision of HR information on the intranet meant that both managers and employees had a higher level of HR knowledge.

\section{Strategic orientation}

Only four of the case study organisations had aimed to increase the strategic orientation of the HR function, although these organisations had not defined this as the execution of business strategy. The CPS's aimed to produce a system that could be:

Developed to provide strategic information on promotion rates, turnover rates and assist with modelling manpower systems for planning purposes. This will, for example, provide opportunities for exploring "what if" scenario planning when HR strategies are being developed.

Similarly, BSkyB aimed to provide a platform for transforming the HR model into one which was more strategic. IBM introduced e-HRM in conjunction with the creation of the role of "HR partner" that focuses on higher level strategic activity.

The actual impact of e-HRM was less clear, although seven organisations described outcomes that could be described as increasing the strategic orientation of the HR function. In BOC, Cancer Research UK, Norwich Union and Nortel these outcomes were unintended as improving the strategic orientation of HR had not been a goal when introducing e-HRM. In the CPS there was no evidence of HR becoming more strategic in the long-term despite this being one of their goals for using e-learning.

Transformational outcomes were explained as a result of the increased availability of accurate and detailed information or of the additional time available to HR practitioners. EHRM within Cancer Research UK enabled the HR team to produce statistics regarding a variety of HR processes, which were used as a basis for HR and managerial decisionmaking and the role of 'People Data Manager' was created specifically to produce HR reports. This improved the credibility of the HR role, aided HR's advisory role and was expected to lead to HR becoming a full business partner. TfL had set up a group information 
management team of HR people who ran regular reports and provided data, identifying trends and areas that the business needed to investigate to improve efficiency. According to our interviewees, there had been significant value obtained from having a centralised team with an excellent understanding and knowledge of the data, as they knew the right questions to ask to ensure the correct information was extracted, and they also used consistent assumptions when running the reports.

In some organisations, e-HRM had facilitated a change in HR structure. TfL used the implementation of e-HRM to facilitate the introduction of HR shared services and found that business partners' roles had changed from being a time ratio of 70:30 time spent on administration to strategy to a ratio of $30: 70$, allowing them to focus on strategic projects. BSkyB and an NHS Trust had used the introduction of e-HRM to facilitate the change to a shared services based HR structure with the aim of creating a more customer-centric HR department. An interviewee from BSKyB explained:

Historically, Business HR is the first point of contact for managers so can become a bottle neck for everything that goes on...... The new system frees their time and means that they can be proactive business partners, can identify the direction of the business in terms of people and look at the abilities and development needs of people.

No organisations provided more than anecdotal evidence for a move to a more strategic role, or increased HR involvement in business strategy. This shows the difficulty even those employed in HR might have in knowing the extent to which their decisions have a strategic value.

\section{Standardisation}

Four organisations also described goals related to standardising practices, to allow benchmarking across the organisation (NHS) or to provide "consistency in quality and a commonality of approach in the training or information sharing resources for staff'. (CPS) 
However, none of the organisations mentioned that this might be advantageous for compliance reasons.

Seven organisations suggested that the use of a common system had led to more consistent HR processes. NHS Trusts had previously managed HR processes independently and in different ways, hence it was impossible to benchmark processes across the NHS. It is interesting to note that standardisation of processes was an outcome of e-HRM introduction even in some organisations for which this had not been an espoused goal, making this a positive unintended outcome.

\section{Organisational image}

We added a sixth goal of organisational image as a result of the second, inductive, stage of analysis. This goal emerged from the literature as six organisations described goals related to the image of the organisation. In some cases this was based upon existing high levels of technological sophistication in organisations. An interviewee at Cancer Research UK explained that they:

Wanted to maintain our cutting edge image. The current model of good practice in $H R$ is to use automated recruitment systems so we needed to follow this practice. The organisation generally has an up to date image. It felt strange not to have an online recruitment system given that we are so large and world class.

Respondents in these six organisations believed that the introduction of e-HRM had a positive impact on their organisational image, although there were no data to independently verify this.

\section{Factors affecting the realisation of e-HRM goals}

The inductive analysis also allowed us to identify a number of factors that might have an impact on whether e-HRM goals were translated into actual outcomes. These factors that emerged from the analysis, are presented below in the order of their significance (those that were mentioned most are presented first). 
HR skills

Five organisations demonstrated that changes to service delivery or to the HR role require the development of new skills within the HR team. Interviewees described how the HR function needed to have consultancy, strategic thinking, analytical, advanced communication, negotiation, process engineering, project management and business writing skills. These are skills that may not already exist within the HR function but which might be necessary in order to achieve the required improvements in service delivery and the move to a strategic HR role.

Training in e-HRM use

Four organisations suggested that providing sufficient training for users of the e-HRM system was an important factor that might affect the outcomes of e-HRM use. In BSkyB and $\mathrm{BOC}$, the systems were not providing the desired efficiency savings as users frequently contacted HR or the HR call centre to obtain support. An interviewee from Cancer Research UK suggested that more time to practice on the system would have been useful, so that staff needed less support after the system went live. In Norwich Union, a number of interviewees did not appear to be aware of the full functionality of the system and were therefore not taking advantage of this.

\section{Engagement with e-HRM}

Interviewees from three organisations discussed the importance of managers and employees engaging with a new e-HRM system in order for it to be accepted and used within the organisation. Norwich Union and BOC had experienced difficulties in encouraging managers and employees to engage with the e-HRM system as several managers complained that using e-HRM was "not a good use of their time" some still used traditional offline systems,. An interviewee from BSkyB emphasised the importance of encouraging 
people to "change their mindset". This resulted in delays in the adoption of e-HRM and in gaining benefits.

Design of the e-HRM system

In BOC, the design of the e-HRM system itself may have affected the outcomes of the introduction of that system (and therefore the realisation of goals). Interviewees suggested that the system was not user friendly or intuitive; one interviewee described the system as "slow and tedious" and actually increasing the amount of administration necessary for managers rather than reducing it. However, this finding may not be generalizable to other organisations.

\section{Familiarity with technology}

A number of interviewees within IBM suggested that, because the organisation has a culture which readily accepts the use of technology, it was easier for them to introduce e-HRM systems and to realise the benefits of these systems. Other interviewees in IBM suggested that older workers or those not familiar with the internet may not obtain the same benefits from e-HRM systems. It is not clear if this finding is generalizable to other organisations.

\section{Discussion}

Our study provided evidence for each of the goals identified through the literature. In addition, we added the goal and outcome of "organisational image".

Efficiency and service delivery goals were stated and achieved by most organisations, evidence which supports the previous work in this area (Ruta, 2005; Ruel et al.,2004). Only Nortel had not at that stage achieved all of their efficiency objectives, maybe because these had not yet been assessed. Service delivery improvements were generally achieved, supporting improved effectiveness of the HR function as an outcome of e-HRM (Gardner et al., 2003; Bondarouk et al., 2009; Payne et al., 2009). Marks and Spencer 
aimed to improve the performance information available but had not at this stage achieved this outcome. Interestingly, both IBM and Nortel showed evidence of the improved service delivery as an unintended positive outcome of e-HRM, while IBM and BOC experienced the unintended negative outcome of the depersonalisation of HRM.

Our findings support Ruel et al. (2004) that another potential goal for e-HRM is to standardise HR processes across an organisation. Standardisation is an outcome that is both achieved through the realisation of a stated goal and as an unintended outcome. This can be seen as a strategically significant outcome as it improves the management process. We also found evidence of relational outcomes of e-HRM (Lepak and Snell, 1998). With the exception of anecdotal evidence in Cancer Research UK, there was no evidence that those organisations who had aimed to improve their image had achieved this. However, it must be recognised that this is an intangible outcome and would be very difficult to evaluate. Interestingly, the organisation that provided the most anecdotal evidence for an improvement in organisational image was the CPS, who had not stated this as a goal for e-HRM introduction.

We identified a number of factors that may have an impact on whether or not the broad goals of e-HRM are realised. In the case of efficiency and effectiveness outcomes, it appears that these may be in part dependent on the design and implementation of the eHRM system itself and upon the thorough training of users of the system. This supports previous work on technology acceptance generally (Davis, 1989). Our research also showed that it is essential that managers and employees are fully engaged with the use of e-HRM. These findings go some way to explain blockages in the path between the broad goals stated at the introduction of e-HRM and the eventual outcomes of using e-HRM.

It might be that what is actually practical and achievable as an outcome is different to those impacts stated as goals. The goals stipulated for the introduction of an e-HRM system should be clear and realistic. In our case study organisations, goals to improve efficiency were often not accompanied with actual figures for cost reductions. Goals to improve the HR function's strategic orientation were often inferred. 
The measurement of management processes is difficult. One of the benefits of eHRM systems is that, when designing systems, attempts to codify and describe management processes are likely to have been made (Tyson and Selbie, 2004). Where costs could be attributed to the processes in managing people, these could be identified and measured. In a number of our case study organisations it was somewhat difficult to assess the magnitude of outcomes or to gather evidence for whether goals had been realised.

Only a few organisations included developing a strategic HR orientation as a goal for e-HRM introduction and not all of these claimed that this had been achieved. Other organisations claimed a transformational impact of e-HRM as an unintended outcome of its introduction. This provides some support for previous work suggesting a strategic impact of e-HRM (Ruel et al., 2004; Olivas-Lujan et al., 2007; Parry, forthcoming). It should be noted however that a more "strategic orientation" as defined by our interviewees may not necessarily mean an increased involvement in implementing business strategy, as described by the SHRM literature (Wright and MacMahon, 1992; Martin-Alcazar et al., 2005).

While many of our case study organisations were providing a better service to their internal customers and reducing headcount, there was little evidence that they were actually contributing more to business decisions. The introduction of e-HRM alone is not sufficient for an HR function to become "strategic". Nevertheless, much of HR activity is in support of corporate strategies, for example by developing organisational capability, through better resourcing and learning systems, helping to clarify strategic choices through more accurate data on costs and performance, and by implementing strategy through effective processes and better organisation. E-HRM has a part to play in all of this as illustrated in the case studies described.

The fact that fewer resources are required than to operate a manual system could provide time and budget for more strategic level work. Our study showed that generally, time available to HR practitioners was being used to improve service delivery. Also, some HR work, the recruitment process for example, is usually managed at a fairly junior level. Therefore, the release of more junior HR managers' time is unlikely to produce more time for 
strategic activity; rather it will offer opportunities for efficiency savings, with reduced HR headcount. Nor is the budget saving necessarily reinvested in more senior HR specialists, but might, for example, be used to absorb the cost of new e-recruitment, or e-HRM, systems. Improved effectiveness or transformational outcomes may be limited by the skill levels of the HR team - as these outcomes invariably require new areas of expertise such as technical, consultancy or project management skills. This supports the findings of Zhang and Wang (2006) that a lack of competent staff may impede the realisation of benefits of eHRM. Without such skills development, it may not be possible for existing HR staff to step into more strategic roles.

E-HRM means that comprehensive data about employees are available, that could be valuable in strategic planning and decision-making. Our study provided some evidence that data is being used for more strategic workforce planning and to support discussions with senior management. However, for data to be used strategically requires there to be an organisational need, well understood at the time of the system design, which incorporates the collection and analysis of strategically valuable data, and also for HR staff to possess skills in statistical analysis so they can go beyond descriptive statistics into studies of causes, forecasting and of variation. Thus, the capability of the system to generate data depends on prior knowledge of what data is required, and the skills and knowledge of how to analyze the data meaningfully. There was no strong evidence that these factors had been considered in the design of the systems in our study. Nevertheless, e-enabled policies such as e-learning and e-recruitment offer solutions not previously possible.

\section{Conclusions}

We have shown that e-HRM is introduced by organisations to improve efficiency and service delivery, to increase the strategic orientation of the HR function, to improve standardisation and organisational image and to empower managers. E-HRM outcomes are mainly related to efficiency, service delivery and standardization, relational outcomes and potential improvements in organisational image. We have provided some evidence for a strategic 
impact of e-HRM through enabling HR to support the organisation in achieving its strategic aims through improved efficiency and effectiveness. However, the realisation of improved efficiency and effectiveness is dependent on the design and implementation of the system and increased effectiveness and involvement in delivering the business strategy may depend on appropriate redeployment and up-skilling of HR staff.

This study may be limited by the inclusion of a number of organisations which had implemented e-HRM technology relatively recently as the impact of e-HRM might become greater over time. In particular we should note that the data were gathered in 2006-2007, therefore there will have been developments in e-HRM in these organisations since that time. Our organisations use of e-HRM mainly focused on the use of relatively basic e-HRM functionality, with only IBM using e-HRM for activities such as performance management. Another limitation could be that our case studies covered mostly larger organisations. The impact of e-HRM may be particularly great in large organisations (Ball, 2001), where the number of employees is such that the automation of processes is cost effective. Further research into the impact of e-HRM in smaller organisations is needed. Although we cannot claim our sample is representative, this study is intended as an exploratory study so confirmatory research and further exploration in this area should be conducted in order to validate our findings.

We have provided empirical evidence for the stated goals and actual outcomes of eHRM and provided some insight into the factors that might affect the realisation of goals. We have therefore made several contributions to the literature on e-HRM. Firstly, we have provided a rare empirical study that has examined both goals and related outcomes of eHRM together. Secondly, we have identified a number of factors that might affect the achievement of goals for e-HRM. This is important as it has practical implications for the design and implementation of e-HRM. Thirdly, we have added to the discussion on whether e-HRM can affect the strategic orientation of the HR function and we have weighed the evidence on how this is realised in practice. 


\section{References}

Ball, K. (2001). 'The use of human resource information systems'. Personnel Review, 30: $5 / 6,677-693$.

Bondarouk, T. and Ruel, H. (2009). 'Electronic human resource management: Challenges in the digital era'. International Journal of Human Resource Management, 20: 3, 505514.

Bondarouk, T., Ruel, H.and van der Heijden, B. (2009). 'E-HRM effectiveness in a public sector organization: A multi-stakeholder perspective'. International Journal of Human Resource Management, 20: 3, 578-590.

CIPD, (2005). People management and technology: progress and potential. London, CIPD.

Burbach, R. and Dundon, T. (2005). 'The strategic potential of human resource information systems: Evidence from the Republic of Ireland'. International Employment Relations Review, 11: 1/2, 97-117.

Davis, F. D. (1989). Perceived usefulness, perceived ease of use, and user acceptance of information technology. MIS Quarterly, 13(3), 319-340.

Enshur, E., Nielson, T. and Grant-Vallone, E. (2002). 'Tales from the hiring line: effects of the internet technology on HR processes'. Organizational Dynamics, 31: 3, 224-244.

Florkowski, G. and Olivias-Lujan, M. (2006). 'The diffusion of human resource informationtechnology innovations in US and non-US firms'. Personnel Review, 35: 6, 684-710.

Gardner, S., Lepak, D. and Bartol, K. (2003). 'Virtual HR: The impact of information technology on the human resource professional'. Journal of Vocational Behaviour, 63: 2, 159-179.

Guest, D. and Peccei, R. (1994). 'The nature and cause of effective human resource management'. British Journal of Industrial Relations, 32: 2, 219-242.

Gueutal, H.G. and Stone, D.L. (2005). The brave new world of eHR: Human resources management in the digital age. San Francisco: Jossey-Bass. 
Hart, S. and Banbury, C. (1994). 'How strategy making processes can make a difference'. Strategic Management Journal, 15: 4, 251-269.

Hendrickson, A. (2003). 'Human resource information systems: Backbone technology for contemporary human resources'. Journal of Labor Research, 24: 3, 381-394.

Jackson, S. and Schuler, R.S. (1995). 'Understanding human resource management in the context of organizational environments', in N.R. Rosen Zurig and L.W. Porter (eds). Annual Review of Psychology, 46: 29-37.

Lepak, D. and Snell, S. (1998). 'Virtual HR: Strategic human resource management in the $21^{\text {st }}$ century'. Human Resource Management Review, 8: 3, 215-234.

Marler, J. (2009). Making human resources strategic by going to the Net: reality or myth? International Journal of Human Resource Management, 20: 3, 515-527

Martin, G., Redddington M. and Alexander, H. (2008). Technology, Outsourcing and Transforming HR. Oxford, UK: Elsevier.

Martin-Alcazar, F., Romero-Fernandez, P. and Sanchez-Gardev, G. (2005). 'Strategic human resource management: Intergrating the universalistic, contingent, configurational and contextual perspectives'. International Journal of Human Resource Management, 16: 633-659.

Mintzberg, H. and Waters, J.A. (1985). 'Of strategies, deliberate and emergent'. Strategic Management, 6, 257-272.

Olivas-Lujan, M.R., Ramirez, J. and Zapata-Cantu, L. (2007). 'E-HRM in Mexico: Adapting innovations for global competitiveness'. International Journal of Manpower, 28: 5, 418-434.

Paauwe, J. (2004). HRM and Performance. Oxford: Oxford University Press.

Parry, E. (forthcoming). 'An examination of e-HRM as a means to increase the value of the HR function'. International Journal of Human Resource Management.

Payne, S.C., Horner, M.T., Boswell, W.R., Schroeder, A.N. and Stine-Cheyne, K.J. (2009). 'Comparison of online and traditional performance appraisal systems'. Journal of Managerial Psychology, 24: 6, 526-544. 
Quinn, J.B. (2003). 'Strategic change: Logical incrementalism', in J.B. Quinn and H. Mintzberg, The Strategy Process ( $4^{\text {th }}$ Edition). USA: Prentice Hall

Ruel, H., Bondarouk, T. and Looise, J. (2004). 'E-HRM: Innovation or irritation. An explorative empirical study in five large companies on web-based HRM'. Management Revue, 15: 3, 364-381.

Ruel, H., Bondarouk, T. and Van der Velde, M. (2007). 'The contribution of e-HRM to HRM effectiveness'. Employee Relations, 29: 3, 280-291.

Ruta, C. (2005). 'The application of change management theory to HR portal implementation in subsidiaries of multinational corporations'. Human Resource Management, 44: 1, 35-53.

Strohmeier, S. (2007). 'Research in e-HRM: Review and implications'. Human Resource Management Review, 17: 19-37.

Strohmeier, S. and Kabst, R. (2009). 'Organizational adoption of e-HRM in Europe: An empirical exploration of major adoption factors'. Journal of Managerial Psychology, 24: $6,482-501$.

Tansley, C., Newell, S. and Williams, H. (2001). 'Effecting HRM-style practices through an integrated human resource information system'. Personnel Review, 30: 3, 351-370.

Thite, M. and Kavanagh, M. (2009). 'Evolution of human resource management and human resource information systems: the role of information technology', in M. Kavanagh and M. Thite, Human Resource Information Systems: Basics, Applications and Future Directions. Thousand Oaks: Sage.

Tyson, S. (1995). Human resource strategy: Towards a general theory of human resource management. London: Pitman/Pearson.

Tyson, S. and Selbie, D. (2004). 'People processing systems and human resource strategy'. International Journal of Human Resources Development and Management, 4: 2, 117127.

Ulrich, D. (1997). Human Resource Champions, Boston: Harvard Business School Press. 
Voermans, M. and Van Veldhoven, M. (2007). 'Attitude towards e-HRM: An empirical study at Philips'. Human Resource Management Digest, 36: 6, 887-902.

Wright, P. and McMahan, G. (1992). 'Theoretical perspectives for strategic human resource management'. Journal of Management, 18: 295-320.

Zhang, L. and Wang, H. (2006). 'Intelligent information processing in human resource management: An implementation case in China'. Expert Systems, 23: 5, 356-369. 
Table 1: Interviews and focus groups per case study

\begin{tabular}{|l|c|}
\hline Case Study & No. interviews \\
\hline BOC & 8 \\
\hline BSkyB & $9+2$ focus groups \\
\hline Cancer Research UK & 11 \\
\hline Crown Prosecution Service (CPS) & 3 \\
\hline IBM & 15 \\
\hline Marks and Spencer & 3 \\
\hline National Health Service (NHS) & 10 \\
\hline Nortel & 3 \\
\hline Norwich Union & $4+3$ focus groups \\
\hline Transport for London (TfL) & 4 \\
\hline
\end{tabular}


Table 2: Summary of case study organisations

\begin{tabular}{|c|c|c|c|c|}
\hline Company & Nature of business & $\begin{array}{l}\text { Approx. } \\
\text { no. } \\
\text { employees }\end{array}$ & Nature of HR provision & HR technology used \\
\hline $\mathrm{BOC}$ & $\begin{array}{l}\text { Large manufacturer } \\
\text { of industrial gases } \\
\text { based in } 50 \\
\text { countries }\end{array}$ & 2,000 & $\begin{array}{l}\text { Five functional HR } \\
\text { teams, supported by a } \\
\text { central support team. }\end{array}$ & $\begin{array}{l}\text { Used a SAP HR } \\
\text { system since } 1999 \text { to } \\
\text { hold HR data and allow } \\
\text { managers to access } \\
\text { this data via the line } \\
\text { manager's desktop in } \\
\text { order to record } \\
\text { absence, enter bonus } \\
\text { ratings and salary } \\
\text { review details. The } \\
\text { system drove the } \\
\text { payroll process. } \\
\text { Introduced an e- } \\
\text { recruitment system in } \\
2003 \text { with a recruitment } \\
\text { database that sat } \\
\text { centrally and was } \\
\text { connected to a number } \\
\text { of different career } \\
\text { centres which each } \\
\text { had a different URL, } \\
\text { behind the scenes } \\
\text { processing and } \\
\text { application form. The } \\
\text { HR intranet had also } \\
\text { recently been re- } \\
\text { launched. }\end{array}$ \\
\hline $\begin{array}{l}\text { British Sky } \\
\text { Broadcasting }\end{array}$ & $\begin{array}{l}\text { UK's largest digital } \\
\text { pay television } \\
\text { platform }\end{array}$ & 10,500 & $\begin{array}{l}\text { Tiered HR structure } \\
\text { with technology at the } \\
\text { front end supported by } \\
\text { a service centre based } \\
\text { HR Delivery } \\
\text { department for } \\
\text { transactional services, } \\
\text { Business HR for } \\
\text { relationship based } \\
\text { proactive services and } \\
\text { centres of excellence } \\
\text { across HR disciplines. } \\
\text { centres }\end{array}$ & $\begin{array}{l}\text { HRIS including } \\
\text { manager and } \\
\text { employee self-service } \\
\text { functionality. } \\
\text { Managers and } \\
\text { employees could } \\
\text { access information } \\
\text { about HR policies and } \\
\text { practices and } \\
\text { managers could view, } \\
\text { report and change } \\
\text { employee details and } \\
\text { process leave } \\
\text { applications. }\end{array}$ \\
\hline $\begin{array}{l}\text { Cancer } \\
\text { Research UK }\end{array}$ & $\begin{array}{l}\text { Charity dedicated to } \\
\text { Cancer Research }\end{array}$ & 3,500 & $\begin{array}{l}\text { Resourcing and } \\
\text { employee relations } \\
\text { team providing advice }\end{array}$ & $\begin{array}{l}\text { End to end e- } \\
\text { recruitment system, } \\
\text { ability to perform } \\
\text { complex calculations }\end{array}$ \\
\hline
\end{tabular}




\begin{tabular}{|c|c|c|c|c|}
\hline & & & and transactional HR. & $\begin{array}{l}\text { and a comprehensive } \\
\text { HRIS, with plans for } \\
\text { self-service } \\
\text { functionality at the time } \\
\text { of the case study }\end{array}$ \\
\hline $\begin{array}{l}\text { Crown } \\
\text { Prosecution } \\
\text { Service }\end{array}$ & $\begin{array}{l}\text { Central part of UK } \\
\text { Criminal Justice } \\
\text { System (public } \\
\text { sector) to ensure } \\
\text { that right cases are } \\
\text { brought, correct } \\
\text { charges and made } \\
\text { and cases } \\
\text { prosecuted } \\
\text { effectively }\end{array}$ & 8,500 & $\begin{array}{l}\text { Headquarters team of } \\
\text { HR staff responsible } \\
\text { for HR strategy, } \\
\text { planning and policies; } \\
\text { regional business } \\
\text { partners and learning } \\
\text { and development } \\
\text { specialists; HR service } \\
\text { centre for routine } \\
\text { transactions. }\end{array}$ & $\begin{array}{l}\text { "The Prosecution } \\
\text { College" - a } \\
\text { comprehensive e- } \\
\text { learning system to } \\
\text { enable lawyers and } \\
\text { other staff to obtain } \\
\text { appropriate skills and } \\
\text { knowledge and remain } \\
\text { up to date. }\end{array}$ \\
\hline IBM & $\begin{array}{l}\text { Large global IT } \\
\text { company }\end{array}$ & 20,000 & $\begin{array}{l}\text { HR organised globally, } \\
\text { in geographical } \\
\text { regions and by } \\
\text { country; shared- } \\
\text { services centre }\end{array}$ & $\begin{array}{l}\text { Dispersed workforce } \\
\text { communicated widely } \\
\text { using IT - telephone, } \\
\text { email and instant } \\
\text { messaging; provided } \\
\text { with laptops; HR } \\
\text { information provided } \\
\text { via the intranet; self- } \\
\text { service tools for } \\
\text { managers. }\end{array}$ \\
\hline $\begin{array}{l}\text { Marks and } \\
\text { Spencer }\end{array}$ & Large retail chain & 68,000 & $\begin{array}{l}\text { Loosely based on } \\
\text { Ulrich model; centres } \\
\text { of excellence and } \\
\text { shared service centre; } \\
\text { split by Head Office } \\
\text { and retail. }\end{array}$ & $\begin{array}{l}\text { Range of technological } \\
\text { tools for HRM; main } \\
\text { HRIS plus payroll and } \\
\text { personnel data, } \\
\text { pensions and absence } \\
\text { management systems; } \\
\text { HR portal for } \\
\text { information on policies } \\
\text { and practices. }\end{array}$ \\
\hline $\begin{array}{l}\text { National } \\
\text { Health } \\
\text { Service } \\
\text { (NHS) }\end{array}$ & $\begin{array}{l}\text { Public sector } \\
\text { provider of UK } \\
\text { health care }\end{array}$ & $>1$ million & $\begin{array}{l}\text { Split into Trusts that } \\
\text { are each managed } \\
\text { locally by a HR team }\end{array}$ & $\begin{array}{l}\text { Electronic Staff Record } \\
\text { (ESR) being } \\
\text { implemented } \\
\text { nationally; contained } \\
\text { core HR and payroll } \\
\text { modules, recruitment, } \\
\text { learning, absence } \\
\text { management, } \\
\text { employee and } \\
\text { manager self-service. }\end{array}$ \\
\hline $\begin{array}{l}\text { Norwich } \\
\text { Union }\end{array}$ & $\begin{array}{l}\text { Large UK insurer, } \\
\text { part of global } \\
\text { insurer, Aviva. }\end{array}$ & 33,000 & $\begin{array}{l}\text { HR business partners, } \\
\text { centres of excellence } \\
\text { and HR customer } \\
\text { services, comprised of }\end{array}$ & $\begin{array}{l}\text { Oracle HR system, } \\
\text { with extensive } \\
\text { manager self-service } \\
\text { for performing salary }\end{array}$ \\
\hline
\end{tabular}




\begin{tabular}{|c|c|c|c|c|}
\hline & & & $\begin{array}{l}\text { learning and } \\
\text { development, HR } \\
\text { change and } \\
\text { communication, } \\
\text { management } \\
\text { information and } \\
\text { planning and HR } \\
\text { systems. }\end{array}$ & $\begin{array}{l}\text { changes, cost centre } \\
\text { and allowances } \\
\text { changes, processing } \\
\text { leavers, updating and } \\
\text { reporting absence, } \\
\text { processing overtime } \\
\text { payments and } \\
\text { comparing salary and } \\
\text { performance ratings; } \\
\text { Also employee self- } \\
\text { service to maintain } \\
\text { personal details, look } \\
\text { at payslips, request } \\
\text { holidays and record } \\
\text { absence. }\end{array}$ \\
\hline Nortel & $\begin{array}{l}\text { Global (North } \\
\text { American) } \\
\text { telecommunications } \\
\text { company }\end{array}$ & 2,000 & $\begin{array}{l}\text { HR based on Ulrich } \\
\text { model with HR shared } \\
\text { service centres in four } \\
\text { locations globally, six } \\
\text { HR delivery teams, } \\
\text { four core HR strategy } \\
\text { groups and a number } \\
\text { of business partners } \\
\text { supporting different } \\
\text { parts of the business. }\end{array}$ & $\begin{array}{l}\text { SAP introduced in late } \\
\text { 1990s manager and } \\
\text { employee self-service } \\
\text { modules deployed in } \\
2005 \text {. }\end{array}$ \\
\hline $\begin{array}{l}\text { Transport for } \\
\text { London ( } \mathrm{TfL} \text { ) }\end{array}$ & $\begin{array}{l}\text { Public sector body } \\
\text { responsible for } \\
\text { London's transport } \\
\text { system. }\end{array}$ & 20,000 & $\begin{array}{l}\text { Each of three } \\
\text { operating businesses } \\
\text { had its own HR } \\
\text { Director and a team of } \\
\text { business partners; } \\
\text { Group HR had a } \\
\text { number of HR teams } \\
\text { that either set strategy } \\
\text { or worked across the } \\
\text { businesses. }\end{array}$ & $\begin{array}{l}\text { SAP Enterprise } \\
\text { Resource Planning } \\
\text { (ERP) system was } \\
\text { introduced covering } \\
\text { finance, procurement } \\
\text { and HR; employee and } \\
\text { manager self-service } \\
\text { tools. }\end{array}$ \\
\hline
\end{tabular}


Table 2: Goals (G) for the introduction of e-HRM and the realization of these through outcomes (0).

\begin{tabular}{|c|c|c|c|c|c|c|c|c|c|c|}
\hline \multirow[t]{2}{*}{ Firm } & \multicolumn{2}{|c|}{ Operational goals \& efficiency } & \multicolumn{2}{|c|}{ Service delivery } & \multicolumn{2}{|c|}{ Strategic orientation } & \multicolumn{2}{|c|}{$\begin{array}{l}\text { Global orientation or } \\
\text { standardisation }\end{array}$} & \multicolumn{2}{|c|}{ Empowerment of managers } \\
\hline & $G$ & $\mathrm{O}$ & $G$ & $\mathrm{O}$ & G & $\mathrm{O}$ & $\mathrm{G}$ & $\mathrm{O}$ & $G$ & $\mathrm{O}$ \\
\hline $\mathrm{BOC}$ & $\begin{array}{l}\text { Improve } \\
\text { visibility of } \\
\text { spend; } \\
\text { reduce } \\
\text { headcount; } \\
\text { quicker } \\
\text { advertising }\end{array}$ & $\begin{array}{l}\text { Reduction in } \\
\text { headcount; } \\
£ 0.5 \text { million } \\
\text { savings in } \\
\text { recruitment } \\
\text { fees }\end{array}$ & $\begin{array}{l}\text { Improve } \\
\text { access to } \\
\text { candidate } \\
\text { inforfmation }\end{array}$ & $\begin{array}{l}\text { Easy access to } \\
\text { information; } \\
\text { improved } \\
\text { accuracy of HR } \\
\text { data; HR team } \\
\text { now have time to } \\
\text { monitor } \\
\text { processes; } \\
\text { depersonalised } \\
\text { HR process }\end{array}$ & & $\begin{array}{l}\text { Reward } \\
\text { team have } \\
\text { time to focus } \\
\text { on strategy; } \\
\text { data } \\
\text { available to } \\
\text { make } \\
\text { strategic } \\
\text { decisions }\end{array}$ & & $\begin{array}{l}\text { Improved } \\
\text { consistency } \\
\text { across parts } \\
\text { of business }\end{array}$ & $\begin{array}{l}\text { Allows } \\
\text { managers to } \\
\text { conduct } \\
\text { recruitment } \\
\text { and perform } \\
\text { HR }\end{array}$ & \\
\hline BSKyB & Cost savings & $\begin{array}{l}\text { Removed } \\
\text { admin } \\
\text { processes } \\
\text { from the HR } \\
\text { team making } \\
\text { the tasks } \\
\text { quicker and } \\
\text { easier; } \\
\text { workload } \\
\text { (calls) of } \\
\text { shared } \\
\text { service centre } \\
\text { initially } \\
\text { increased }\end{array}$ & $\begin{array}{l}\text { Facilitate } \\
\text { modelling of } \\
\text { HR into a } \\
\text { more } \\
\text { customer- } \\
\text { centric } \\
\text { function; } \\
\text { improve } \\
\text { transactional } \\
\text { HR and } \\
\text { customer } \\
\text { service }\end{array}$ & $\begin{array}{l}\text { Improved } \\
\text { accuracy of data } \\
\text { entry; HR team } \\
\text { have time to do } \\
\text { more value- } \\
\text { added work; } \\
\text { more customer } \\
\text { focused; } \\
\text { employees are } \\
\text { better informed }\end{array}$ & $\begin{array}{l}\text { Act as } \\
\text { platform to } \\
\text { change } \\
\text { behaviour } \\
\text { and the } \\
\text { overall HR } \\
\text { model }\end{array}$ & $\begin{array}{l}\text { Time to } \\
\text { identify } \\
\text { direction of } \\
\text { business in } \\
\text { terms of } \\
\text { people and } \\
\text { identify } \\
\text { abilities and } \\
\text { needs to } \\
\text { people }\end{array}$ & & $\begin{array}{l}\text { Consistent } \\
\text { processes } \\
\text { between } \\
\text { business } \\
\text { units }\end{array}$ & $\begin{array}{l}\text { Act as a } \\
\text { platform to } \\
\text { develop new } \\
\text { services; } \\
\text { empower } \\
\text { managers to } \\
\text { conduct HR } \\
\text { activities }\end{array}$ & $\begin{array}{l}\text { Improved } \\
\text { capacity of } \\
\text { managers } \\
\text { through } \\
\text { increased } \\
\text { responsibility }\end{array}$ \\
\hline CR UK & $\begin{array}{l}\text { Cost } \\
\text { savings; } \\
\text { faster and } \\
\text { more } \\
\text { efficient } \\
\text { recruitment; } \\
\text { efficient } \\
\text { management } \\
\text { of } \\
\text { speculative }\end{array}$ & $\begin{array}{l}\text { Redundancy } \\
\& \text { maternity } \\
\text { calculations } \\
\text { take } 5 \\
\text { minutes } \\
\text { rather than } 2 \\
\text { hours; } \\
\text { recruitment } \\
\text { process } 1.5 \\
\text { instead of } 3 \\
\text { months; } \\
\text { reduced }\end{array}$ & $\begin{array}{l}\text { Improve } \\
\text { credibility of } \\
\text { HR; improve } \\
\text { accuracy of } \\
\text { data entry }\end{array}$ & $\begin{array}{l}\text { Improved } \\
\text { transparency of } \\
\text { payment } \\
\text { calculations; } \\
\text { accessible } \\
\text { information to } \\
\text { solve problems; } \\
\text { recruitment data } \\
\text { more accurate; } \\
\text { increased reach } \\
\text { to candidates }\end{array}$ & & $\begin{array}{l}\text { Data to lead } \\
\text { HR into } \\
\text { advisory and } \\
\text { more } \\
\text { strategic } \\
\text { role }\end{array}$ & & & $\begin{array}{l}\text { Allow } \\
\text { managers to } \\
\text { manage } \\
\text { recruitment }\end{array}$ & \\
\hline
\end{tabular}




\begin{tabular}{|c|c|c|c|c|c|c|c|c|c|c|}
\hline & applications & $\begin{array}{l}\text { headcount by } \\
1 \text {; reduced } \\
\text { paper }\end{array}$ & & & & & & & & \\
\hline CPS & $\begin{array}{l}\text { Time } \\
\text { efficiencies; } \\
\text { cost } \\
\text { effectiveness } \\
\text { through } \\
\text { economies } \\
\text { of scale }\end{array}$ & $\begin{array}{l}\text { Reduced } \\
\text { training costs }\end{array}$ & $\begin{array}{l}\text { Ensure } \\
\text { training was } \\
\text { available } \\
\text { across the } \\
\text { CPS; enable } \\
\text { information } \\
\text { sharing }\end{array}$ & $\begin{array}{l}\text { Improved access } \\
\text { to training } \\
\text { materials and } \\
\text { knowledge }\end{array}$ & $\begin{array}{l}\text { Provide } \\
\text { strategic } \\
\text { information } \\
\text { to allow } \\
\text { modelling } \\
\text { of } \\
\text { manpower } \\
\text { for } \\
\text { planning } \\
\text { and } \\
\text { scenario } \\
\text { planning }\end{array}$ & & $\begin{array}{l}\text { Provide a single } \\
\text { information/training } \\
\text { source across the } \\
\text { CPS }\end{array}$ & $\begin{array}{l}\text { Consistent } \\
\text { information } \\
\text { available to } \\
\text { all solicitors }\end{array}$ & & \\
\hline IBM & $\begin{array}{l}\text { Cost } \\
\text { reductions; } \\
\text { efficiency } \\
\text { through } \\
\text { admin } \\
\text { reduction }\end{array}$ & $\begin{array}{l}\text { Reduced } \\
\text { headcount; } \\
\text { reduced } \\
\text { manual input } \\
\text { and data } \\
\text { entry; } \\
\text { reduced cycle } \\
\text { time through } \\
\text { self-service }\end{array}$ & & $\begin{array}{l}\text { Helps managers } \\
\text { to perform HR } \\
\text { activities by a } \\
\text { particular date } \\
\text { Increase in } \\
\text { available } \\
\text { information for } \\
\text { managers; } \\
\text { flexible benefits } \\
\text { system; } \\
\text { depersonalisation } \\
\text { of HR service } \\
\text { and isolation of } \\
\text { employees }\end{array}$ & $\begin{array}{l}\text { Creation of } \\
\text { HR } \\
\text { partners } \\
\text { who focus } \\
\text { on higher } \\
\text { level } \\
\text { strategic } \\
\text { work }\end{array}$ & $\begin{array}{l}\text { HR Partners } \\
\text { have time to } \\
\text { perform } \\
\text { strategic } \\
\text { tasks rather } \\
\text { than } \\
\text { focusing on } \\
\text { people }\end{array}$ & & $\begin{array}{l}\text { Processes } \\
\text { (e.g. } \\
\text { appraisals) } \\
\text { now } \\
\text { conducted in } \\
\text { a consistent } \\
\text { manner }\end{array}$ & $\begin{array}{l}\text { Empowerment } \\
\text { of managers }\end{array}$ & $\begin{array}{l}\text { Managers and } \\
\text { employee have } \\
\text { more HR } \\
\text { knowledge }\end{array}$ \\
\hline $\begin{array}{l}\text { Marks } \\
\text { and } \\
\text { Spencer }\end{array}$ & $\begin{array}{l}\text { Headcount } \\
\text { reduction }\end{array}$ & $\begin{array}{l}\text { Processes } \\
\text { faster and } \\
\text { more } \\
\text { efficient; } \\
\text { overheads } \\
\text { still high due } \\
\text { to high level } \\
\text { of manual } \\
\text { administration }\end{array}$ & $\begin{array}{l}\text { Produce good } \\
\text { quality data to } \\
\text { analyse } \\
\text { performance }\end{array}$ & & & & $\begin{array}{l}\text { Standardise and } \\
\text { centralise } \\
\text { processes across } \\
\text { organisation }\end{array}$ & $\begin{array}{l}\text { Improved } \\
\text { consistency } \\
\text { between } \\
\text { shared } \\
\text { services and } \\
\text { store HR } \\
\text { teams. }\end{array}$ & & \\
\hline $\mathrm{NHS}$ & $\begin{array}{l}\text { Efficiency } \\
\text { through } \\
\text { single data }\end{array}$ & $\begin{array}{l}\text { Less paper; } \\
\text { removed } \\
\text { duplication; }\end{array}$ & $\begin{array}{l}\text { Allow more } \\
\text { effective } \\
\text { managemengt }\end{array}$ & $\begin{array}{l}\text { Improved } \\
\text { flexibility and } \\
\text { reports }\end{array}$ & $\begin{array}{l}\text { Enable the } \\
\text { introduction } \\
\text { of shared }\end{array}$ & $\begin{array}{l}\text { Facilitation } \\
\text { of shared } \\
\text { services to }\end{array}$ & $\begin{array}{l}\text { Standardise } \\
\text { management } \\
\text { information to }\end{array}$ & $\begin{array}{l}\text { Improved } \\
\text { consistency } \\
\text { of HR }\end{array}$ & $\begin{array}{l}\text { Allow } \\
\text { managers to } \\
\text { conduct HR }\end{array}$ & \\
\hline
\end{tabular}




\begin{tabular}{|c|c|c|c|c|c|c|c|c|c|c|}
\hline & $\begin{array}{l}\text { entry; cost } \\
\text { savings }\end{array}$ & $\begin{array}{l}\text { ongoing } \\
\text { issues in } \\
\text { Trusts } \\
\text { preventing } \\
\text { efficiency } \\
\text { savings }\end{array}$ & of staff & & $\begin{array}{l}\text { services } \\
\text { and make } \\
\text { HR more } \\
\text { strategic }\end{array}$ & $\begin{array}{l}\text { allow more } \\
\text { strategic } \\
\text { business } \\
\text { partner role }\end{array}$ & $\begin{array}{l}\text { enable } \\
\text { benchmarking }\end{array}$ & $\begin{array}{l}\text { processes } \\
\text { between } \\
\text { Trusts }\end{array}$ & activities & \\
\hline $\begin{array}{l}\text { Norwich } \\
\text { Union }\end{array}$ & $\begin{array}{l}\text { Removal of } \\
\text { paper; } \\
\text { efficiency } \\
\text { through self- } \\
\text { service and } \\
\text { removal of } \\
\text { duplication; } \\
\text { cost } \\
\text { reduction }\end{array}$ & $\begin{array}{l}\text { Reduced } \\
\text { headcount by } \\
4.0 \text { full time } \\
\text { equivalents } \\
\text { (£120k); } \\
\text { reduced } \\
\text { paper will } \\
\text { save } 1100 k ; \\
\text { faster } \\
\text { processes; } \\
\text { processes } \\
\text { being } \\
\text { duplicated } \\
\text { due to } \\
\text { managers still } \\
\text { using old } \\
\text { systems }\end{array}$ & $\begin{array}{l}\text { Build } \\
\text { functionality to } \\
\text { cope with a } \\
\text { flexible } \\
\text { workforce; } \\
\text { build platform } \\
\text { for improved } \\
\text { service } \\
\text { delivery; } \\
\text { improved } \\
\text { accuracy of } \\
\text { data and } \\
\text { confidence in } \\
\text { system }\end{array}$ & $\begin{array}{l}\text { Improved } \\
\text { accuracy of data; } \\
\text { HR have time to } \\
\text { focus on more } \\
\text { complex jobs; } \\
\text { improved quality } \\
\text { of HR work due } \\
\text { to improved work } \\
\text { flows; information } \\
\text { readily available } \\
\text { for managers }\end{array}$ & & $\begin{array}{l}\text { Reliable } \\
\text { data means } \\
\text { that HR can } \\
\text { make } \\
\text { strategic } \\
\text { decisions } \\
\text { about HR } \\
\text { and what it } \\
\text { can do for } \\
\text { the business }\end{array}$ & & & $\begin{array}{l}\text { Empowerment } \\
\text { of managers } \\
\text { to take } \\
\text { responsibility } \\
\text { for people and } \\
\text { become self- } \\
\text { sufficient }\end{array}$ & \\
\hline Nortel & $\begin{array}{l}\text { Improve } \\
\text { employee } \\
\text { efficiency; } \\
\text { reduce HR } \\
\text { spend }\end{array}$ & & & $\begin{array}{l}\text { Clear objectives } \\
\text { and } \\
\text { communication } \\
\text { for managers; } \\
\text { streamlined } \\
\text { approval system }\end{array}$ & & $\begin{array}{l}\text { Enables } \\
\text { devolvement } \\
\text { of HR to } \\
\text { managers } \\
\text { therefore } \\
\text { allowing } \\
\text { time for HR } \\
\text { to focus on } \\
\text { strategy; } \\
\text { creation of } \\
\text { core HR } \\
\text { strategy } \\
\text { group that } \\
\text { designs } \\
\text { future HR } \\
\text { strategy }\end{array}$ & $\begin{array}{l}\text { Standardise HR } \\
\text { processes and } \\
\text { procedures } \\
\text { globally }\end{array}$ & $\begin{array}{l}\text { Processes } \\
\text { standardised } \\
\text { across the } \\
\text { business }\end{array}$ & & $\begin{array}{l}\text { Improved } \\
\text { manager } \\
\text { effectiveness }\end{array}$ \\
\hline TfL & $\begin{array}{l}\text { Reduce HR } \\
\text { to employee } \\
\text { ratio }\end{array}$ & $\begin{array}{l}\text { Savings of } \\
\text { £8m from } \\
\text { reduced } \\
\text { employee }\end{array}$ & $\begin{array}{l}\text { Enable data- } \\
\text { driven HR } \\
\text { strategy with }\end{array}$ & $\begin{array}{l}\text { Improved } \\
\text { availability of } \\
\text { metrics and } \\
\text { reports }\end{array}$ & & & & & & \\
\hline
\end{tabular}




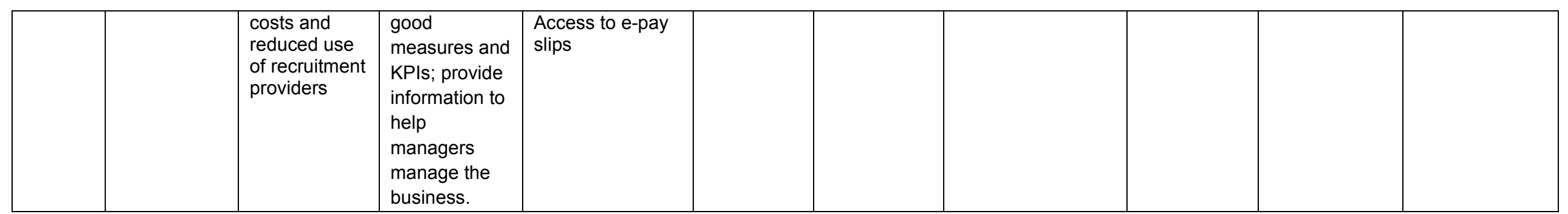

NB: where no information has been entered, this means that no evidence was found through the case studies. 